\title{
A Valuation Model For Assessing Compensation Arising From Oil Spills In The Niger Delta Area Of Nigeria
}

\author{
Babawale Gabriel Kayode, PhD. \\ Department of Estate Management, \\ University of Lagos, Akoka, Lagos, Nigeria. \\ Titilayo Ukabam \\ Department of Estate Management \& Valuation, \\ Yaba College of Technology, Lagos, Nigeria
}

\begin{abstract}
This study proffers an encompassing valuation model that reflects and addresses the multi-faceted, multi-dimensional and multi-disciplinary nature of the issues and activities involved in valuation for compensation for environmental contamination, particularly, oil spills. The ultimate goal of the study is overall improvement in the practice of environmental valuation in the study area in particular, and Nigeria at large. This is expected to eliminate, or at least minimize, the protracted and costly litigations, and social disquietedness often associated with assessment of compensation for oil spillage in the study area. The study is based exclusively on secondary data drawn from relevant documents including results of past studies, valuation professional standards, valuation reports, relevant statutes and case laws as well as the experience of one of the authors as expert witness in cases involving compensation for oil spills in the study area. Specifically, the study is a follow-up to Babawale (2013) which examined certain emerging issues in assessment of compensation for oil spillage in the Niger Delta area of Nigeria but came short of providing appropriate valuation model but rather recommended that further studies be carried out to fill this gap.
\end{abstract}

Key words: compensation, contaminated property, Nigeria, oil spills, valuation model.

\section{INTRODUCTION}

Nigeria is today the largest oil producer in Africa and the sixth largest in the world. The country's proven oil reserves as at January 2011 is estimated at 37.2 billion barrels while natural gas reserves is about 5.29 trillion cubic meters, which is $2.82 \%$ of the world's estimated reserves and the largest in Africa (KPMG, 2014). Nigeria's economy is largely dependent on the oil and gas sector which contributes between $90 \%$ and $95 \%$ of her export earnings, $20 \%$ of GDP and about $40 \%$ of government revenues (Nwilo \& Badejo, 2005). Nigeria's oil and gas reserves exist largely along the coastal Niger River Delta area and offshore to the Bright of Bonny.

Nigeria's fortune from the oil industry has not come without its costs particularly in massive environmental contamination. Since the discovery of oil in Nigeria in the 1950s, oil spills resulting from prospecting, drilling, and transportation activities, operation failure, mechanical failure, natural hazards, and third-party activities in forms of malicious incidents and acts of sabotage have been reported (Achebe, Nneke and Anisiji, 2012; Egbe and Thompson, 2010; Kakulu, Byrne and Viitamen, 2009; Roddewig, 1999). Oil contamination creates problems that disrupt the lives of people living in close proximity to oil wells, pumping stations, camps and pipelines including contamination of drinking water, top soil, and various diseases affecting livestock, humans and aquatic lives. 
When environmental pollution accidents occur, victims often file lawsuits to claim compensation for the damages suffered. To this end, the court often relies on the assistance of Estate Surveyors and Valuers as expert witnesses in arriving at a just and fair decision on the quantum of compensation that is reasonable and adequate in the circumstance. Since a third party's interest is involved and the claims are often substantial, compensation valuations for oil spills ought to be all-encompassing; contain adequate and convincing explanatory data; verifiable and incontrovertible evidences; including strong persuasive and compelling supports for all the data inputs as well as the ultimate valuation opinion. Equally, the report should be sufficiently transparent, objective, traceable and rational. It is transparent when it is easy for a third party to see through the truth; it is traceable where the arguments and reasons that produce the final estimates of costs/values can be easily followed through; and objective where the conclusions are not based on emotion but rather on relevant facts and reliable data.

Babawale (2013), in a content analysis of 30 valuation reports on compensation for oil spills prepared by Valuers operating in the study area, observed, among others, that the valuation model employed by almost all the valuers was inadequate and, in some cases, inappropriate and was largely responsible for the widespread inconsistent and controversial assessment often associated with valuation for compensation in the area. This study primarily seeks to address these flaws. The observed deficiencies included the fact that only a negligible proportion of the valuation reports made reference or reflect relevant provisions of the enabling law or other relevant statutes or civil laws; and in $57 \%$ of the reports, the valuation figures were unsupported with any data and it was not shown how the figures (values) were computed. In a number of the reports, valuers attempted to use, or purportedly used, one or more of the three conventional methods namely: The Comparative method, the Cost Method, and the Income Capitalization method; howbeit in a manner that lack transparency, objectivity, rationality, and consistency. For instance, in using the Cost method, Valuers failed to specify the exact physical state of the object of valuation (e.g. fish fences, fish traps, fish ponds, and hooks) such as the age, size, type, capacity, and construction materials that were valued. Similarly, in calculating compensation for 'disturbance' and 'injurious affection', Valuers employed the income capitalization approach but failed to justify or substantiate the choice of the number of 'years of recovery'; the rationale behind the partitioning of the estimated period for recovery into tranches for purpose of calculation; the estimates of gross incomes from fishing; the proportion of the total loss that is recoverable per period; the estimates for outgoings; and the choice of both the remunerative and accumulative rates. None of the reports used any of the non-market valuation methods such as the contingent method which are particularly relevant for this category of valuation. More disturbing is the finding that only $27 \%$ of the reports included or reflected the inputs of any technical specialists which, rendered the valuers' estimates suspect. It is, for instance, outside the purview of a real estate Valuer to objectively and adequately assess the impact and cost implications of oil spillage on the ecosystem, vegetation, microbes, aquatic lives, and human health without the input of relevant technical specialists. In the absence of such scientific reports/inputs, the Valuers' estimates are regarded as speculative and superfluous.

In summary, faulty or inadequate valuation model has been fingered as the main contributory factor to these flaws and the resultant questionable assessment of compensation which tended to cast aspersion on the reputation and integrity of the valuation profession in the study area. Drawing from international best practice, relevant valuation principles, professional practice standards and ethics, including court precedencies, this paper addresses the observed conceptual shortcomings and proffers a valuation framework that is all-inclusive and that recognizes and allows for the peculiarities of valuation for compensation from oil spills as multi-faced, multi-dimensional and multi-disciplinary. 


\section{VALUATION MODEL}

Modelling is about building a virtual representation of things in the 'real world' that allows ideals to be investigated. It is a way of expressing a particular view of an identifiable system of some kind. A model is a simple description of a system, used for explaining how something works or for calculating what might happen (Hornby, 2018). The efficiency of a model in providing the right solution would depend upon the extent to which the model is a true representation of the problem structure. Regardless of the complexity of the structure of the system that is being modeled, a model must be simple, easy to understand, capable of unequivocal objective interpretation, flexible and involve minimum calculation; it must also satisfy the economy of time, cost and resources (Byrne, 1996).

A valuation framework harmonizes divergent views as to the aggregate concepts, evidence and procedure employed in establishing values. Ifediora (2009) observed that "in the development of valuation practice, there has been considerable divergence in the views of valuers as to the aggregate concepts, evidences and procedure employed in establishing values. In spite of these difficulties, especially over the past two decades continued efforts, particularly in the USA, have been directed towards the establishment of some broad and universally accepted framework for valuation procedure".

The application of appropriate valuation model for assessing compensation for environmental contamination generally, and for damages arising from oil spills in particular, should be of interest not only to the valuation profession but also to owners of impacted properties, the oil prospecting companies, relevant government agencies, lenders, and a host of other stakeholders. Oil spills, a common occurrence within the oil producing Niger Delta area of Nigeria, often affects substantial land area and can persists for several years with attendant grave repercussion on both the health and means of livelihood of people living within the impacted area. Given the magnitude of the consequential loss, the claims for compensation for oil spillage are often very substantial and the controversies which often surround the compensation payable invariable become subject of litigation. In Nigeria, The Estate Surveyor and Valuer are often engaged as expert witness to assist the Court in arriving at the quantum of compensation that is reasonable and fair in the circumstance. Regrettably, valuations of property affected by oil spills or other detrimental occurrences is relatively a budding aspect of the valuation discipline. Both the academia and practitioners are therefore still in search of an ideal or universally acceptable framework that adequately captures and quantifies the nature and extent of damages suffered including the appropriate compensation.

In developing a conceptual model for assessing compensation for oil spills, existing theoretical models developed by previous researchers were reviewed. Babawale (2008) observed that "there are yet little known widely accepted theoretical models on the subject of valuation beside that by Levy and Schuck (1999) which was adopted by Amidu (2006) and also Amidu and Aluko (2007) for their respective studies on client's influence on valuation inaccuracy in Lagos metropolis. To develop their model, Levy and Schuck (1999) had laid the foundation on previous theoretical models which essentially depicted the valuation construction process as both normative and descriptive. The normative model sought to depict valuation construction as a black box process whereby a valuer, in estimating the property value, combined his knowledge of previous valuation with the hedonic prices of property characteristics extracted from previous transaction data. The model hypothesized that, in a world of noisy transaction data, a rational valuer's best estimate of the current value of a property (pt), would be the weighted average of a previous forecast of $\mathrm{Pt}$ at time $\mathrm{t}-1$, a previous valuation and new transaction data (Quan and Quiley, 1991 as cited in Levy and Schuck, 1999). Figure 1 depicts this as a signal processing system. The valuer's task in the process is the filtration and 
interpretation of the property and market information (including knowledge of the property's previous valuation) to produce an estimate of value. The model is classified as normative because the transfer function that characterizes the process within the black box assumes that valuers act rationally and objectively in their interpretation of this information.

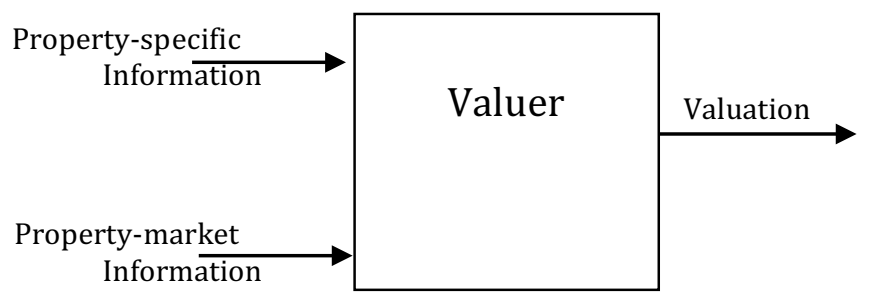

Figure 1: The Normative Model Source: Levy \& Schuck (1999:381)

The desire in later years to understand better the phenomenon of inaccuracy in valuation drew attention to the procedural and particularly, the behavioural aspect of valuation construction process. Borrowing from cognitive psychology, researchers turned through experiments, to seeking an understanding of valuer's characteristics on the valuation process including the effects on valuation of valuer's use of heuristics, departure from normative model, comparable sales selection, feedback and client influence.

Levy and Schuck (1999) observed that the most important contribution of these later studies has been to highlight the implicit role that certain factors and information play in determining the specification of the transfer function which manifests itself as a control signal that affect the parameters of the transfer function, or even the form of the function itself. The resultant descriptive model is as depicted in Figure 2.

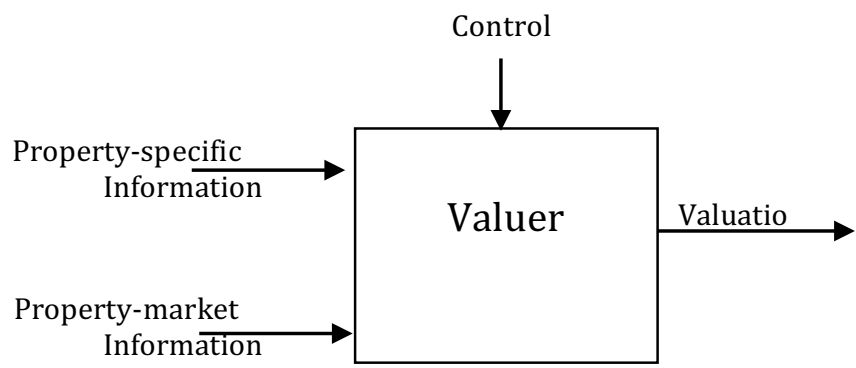

Figure 2: The Descriptive Model

Source: Levy \& Schuck (1999:382)

Both the normative and the descriptive models as depicted in (Fig.1 and Fig.2) are still considered less than adequate to capture and illustrate the complexity that is associated with the valuation process. To address this shortcoming and taking cue from similar studies in auditing and marketing, Levy \& Schuck (1999) came up with a model that provides a more holistic understanding of the means by which clients influence valuation output (see Figure 3) 


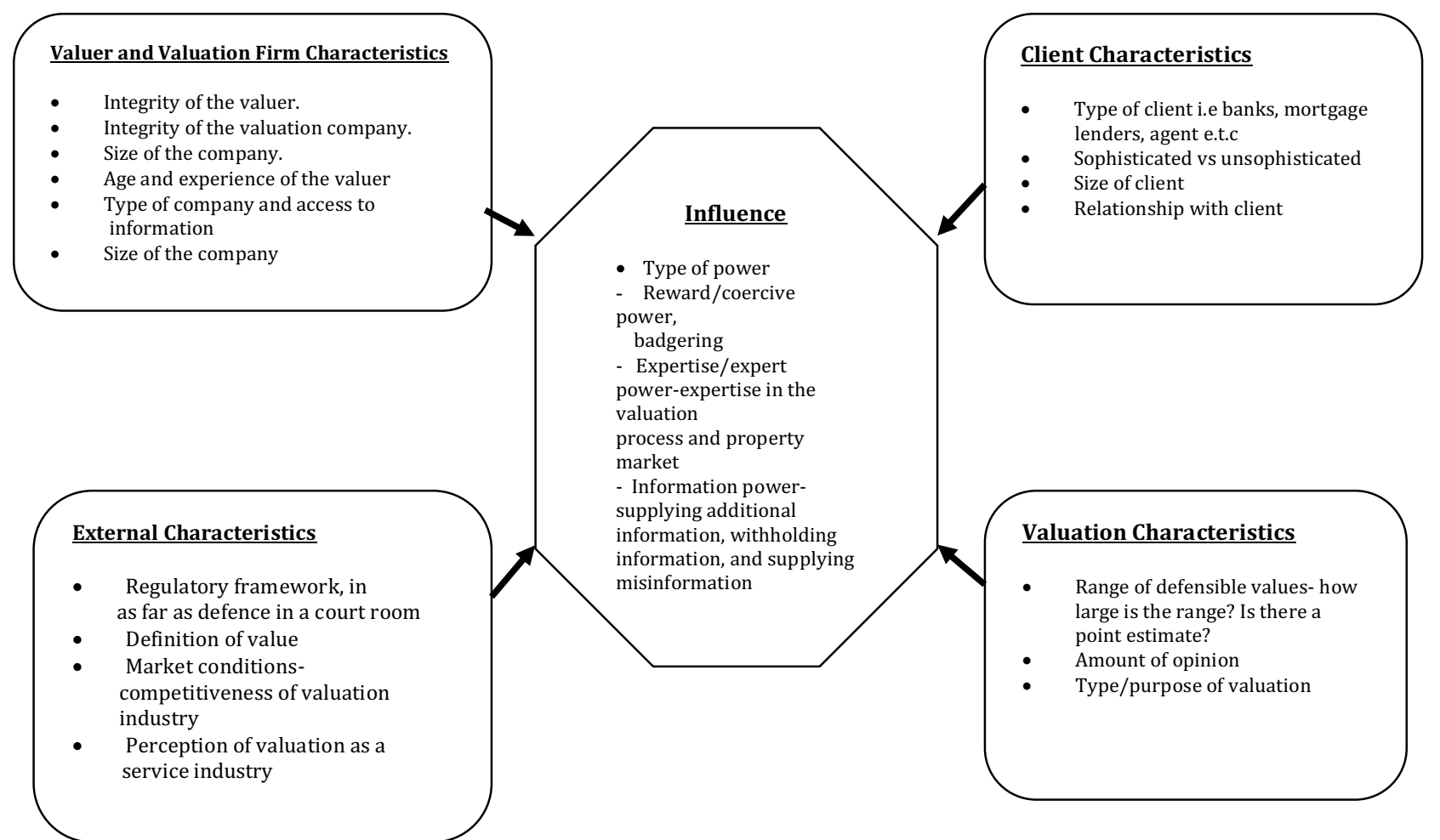

Figure 3: Factors Affecting Client Influence as Reported by Experienced Valuers Source: Levy \& Schuck (1999:395)

Though the model was limited only to client's influence, its holistic approach, its ability to capture a good number of explanatory variables in their respective categories makes its philosophy very relevant and advantageous to the present study. The categorization also allows for more detailed and insightful analyses, while setting the results in a better perspective and offering the advantage of a clearer presentation of the results. Following this more integrated and all-encompassing model, a framework for assessing compensation for environmental pollution which recognizes and make room for the varied and complex nature of factors that affect most valuations has been conceptualized and developed as depicted in Fig.4. The framework shows that assessment of fair and adequate compensation for oil spills is invariably multi-faceted, multi-dimensional, and of course, multi-disciplinary.

\section{A VALUATION MODEL FOR ASSESSING COMPENSATION FOR DAMAGES SUFFERED IN AN INSTANCE OF OIL SPILL}

The universal basis of valuation for compensation is obtaining a cash payment that would reasonably restore the claimant to status quo; that is, put the claimant virtually in the same position as before the incidence. Given that a third party's interest is involved; the penalty is usually substantial; and the controversy often generated would invariably end up in the court; the valuer, like an attorney, must prepare his report mindful that it will invariably be a subject of scrutiny and contention in a law court. The valuation report must therefore be prepared within a framework that is holistic and all-encompassing; that allows for the consideration of all pertinent issues, engagement of relevant specialists, and that none of the essential steps in the valuation process is wittingly or unwittingly omitted or compromised. Hence, the need for a model that captures the complexity and multi-disciplinary nature of assessing compensation for oil spills. The elements that make up the proffered valuation framework include the characteristics of the impact and impacted area; peculiarity of local property market place; relevant statutes and civil laws; results of relevant Scientific or laboratory investigations or tests; relevant case laws, valuation principles and theory; and professional practice standards. 
The framework addresses pertinent issues and considers matters of concern in computing compensation for environmental pollution generally, and for oil spills in particular.

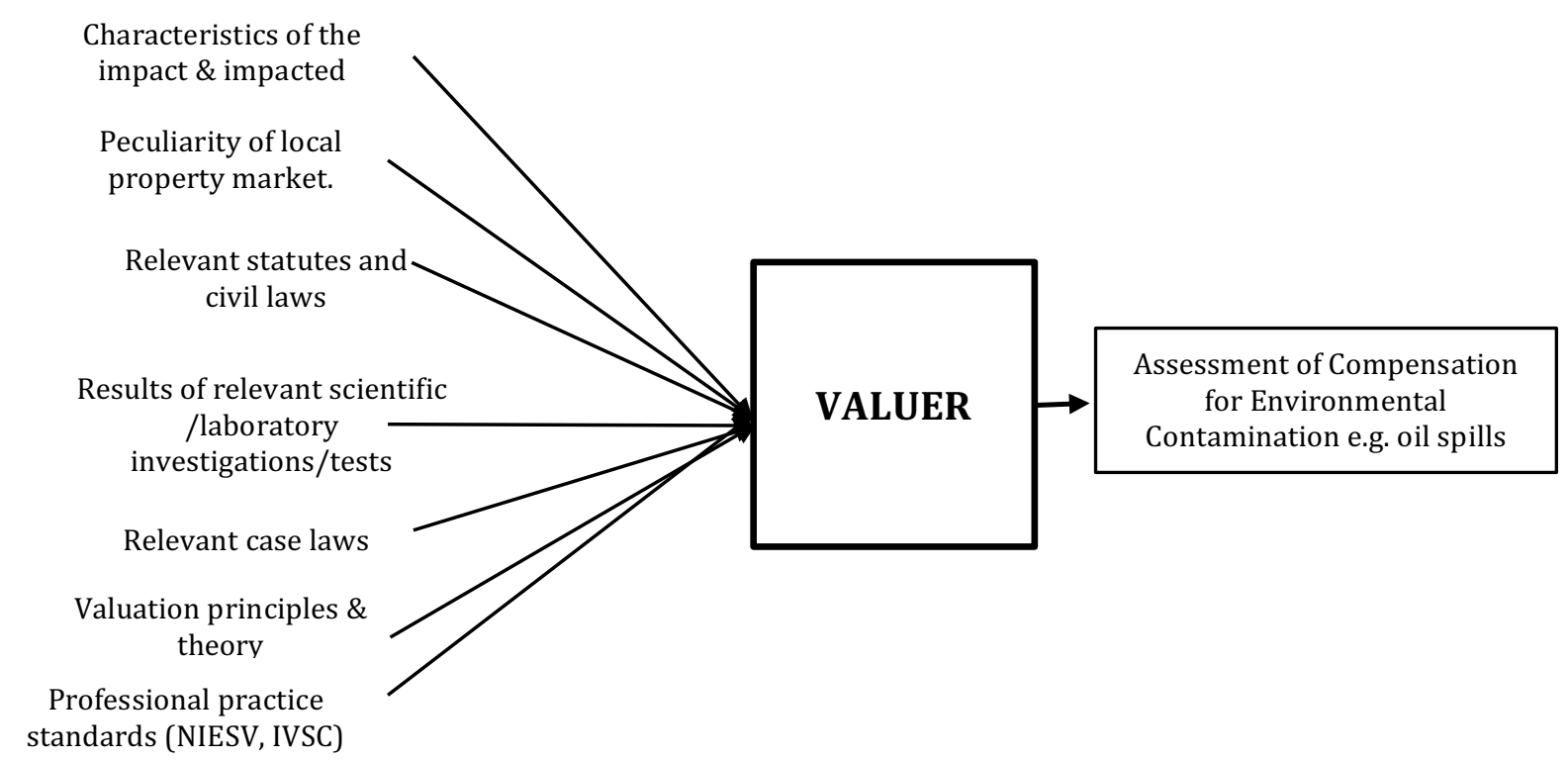

Fig. 43: A model for assessing compensation for environmental contamination. Source: Author

\section{Valuation principles and theory}

In making valuation for compensation for oil spillage, the ordinary principles of valuation generally apply safe that the valuer is expected to pay due attention to the legal positions of the parties as provided by relevant statutes and civil laws, among others. In addition, the impacted area which is the subject of expert evidence must be more thoroughly inspected and preparation of a proof of evidence carried out more painstakingly than would have been done for most other types of valuation assignment. Thus, the Valuer may need to inspect, and reinspect the property in question, undertake extensive measurements, enumerations, inventories and carry out a great deal of both market and industry studies. In his proof of evidence, he must, for instance, give his reasons for every conclusion in anticipation of its being challenged in cross-examination.

Valuers may employ one or a combination of the three market-based valuation models; that is, the income capitalization, the direct market comparison, or the cost methods or any combination of these. Each of this can be appropriately modified to assess the compensation for a number of the 'heads of claims' such as loss of fishing rights, and loss/damage to fishing equipment/facilities (hooks, nets, traps, canoes etc.). All the three methods rest on the principle of substitution which states that no commodity has a value greater than the value of similar commodity offering similar uses, similar utility, and similar function that can be purchased within a reasonable time limit that the buyers' market demands. Each of the methods depends highly on market derived data/evidences to produce reliable value estimates.

The comparative approach derives retrospective market values by analyzing the market transactional evidences of similar properties and comparing them to the subject property. For valid and reliable results, both the subject property and the comparable properties must have at least the potential of a similar or identical, highest and best use. The direct market 
comparison method is therefore ideal for items presently traded in the primary or secondary market such as hooks, nets, boats, and canoes.

The Cost method is the process by which the replacement cost or reproduction cost of an asset is obtained. The method is particularly suited to specialized item(s) that have no close substitutes and that are rarely brought to the market for sale. To use the method requires information on the size, type, brand, age and the exact number of the object of valuation which may need to be authenticated by genuine receipts etc. As Nigeria do not yet have well organized secondary markets for most of the items often encountered in valuation for oil spillage, it is necessary that the valuer possesses some knowledge of the exact physical state of these items to enable him account for accrued depreciation in his valuations. The cost method is particularly appropriate for assessment of compensation for loss of, or damage to fishing ponds, fishing traps, and buildings, among others.

The Income capitalization method converts the future benefits of ownership into an expression of present worth. To produce reliable valuation via this method demands an accurate estimate of gross income, the outgoings and the required yield. The yield which reflects the relative quality or the risk characteristics of the investment must be determined based on proven macro-economic indices and market evidences. The income capitalization is therefore the method to use for the income producing aspects of the damaged or destroyed assets e. g. loss of fishing rights.

The use of the three conventional methods of valuation for capitalizing impairment into property values however suffers certain fundamental shortcomings, both conceptual and empirical. First, environmental valuation, no matter the scale, is inherently spatial and therefore requires the use of analytical framework that extends beyond these three traditional neo-classical economic methods of valuation (Bowman \& Boyle, 2005). Secondly, as Wilson (1992), pointed out "each environmental problem is as unique as a fingerprint". That is, it is very rare to find good, arms-length comparable sale of contaminated properties which are contaminated by similar pollutants, in similar magnitude, in similar manner and in similar environment. Other limitations of the methods include errors of logic and arithmetic, and the implicit nature of yield used in investment method (Baum \& Macgregor, 1992); and the tendency for sale prices to be influenced to some degree by the special needs of purchasers or vendors (Davis, 2010); and the difficulty in accurate quantification of depreciation in existing improvements in Cost Method (Babawale, 2013). In addition, the methods do not have explicit allowance or objective way of accounting for value loss due to the stigma factor. For example, in the capitalization approach, stigma is often arbitrarily accounted for by using an upward adjustment of capitalization rate. Furthermore, environmental contaminants may not only affect tangible items such as land, buildings, plant and machinery but also intangibles such as bio-physical, socio-cultural, economic and health assets. In effect, the effects of oil spills on human health, aquatic lives, vegetation etc. are not adequately captured by these conventional models. Therefore, estimating values for environmental goods demands a considerable broadening of the concept, basis and techniques to accommodate goods that are not marketable but on which society places value even though they are not sold and bought in conventional manners.

A reliable value estimate of environmentally impaired properties would therefore require the application of specialized methods, procedures and formulas that go beyond the limits of the conventional valuation methods and that permit each case to be separately and competently analyzed (Bell, 2008). To this end, the search for veritable alternative valuation approaches that eliminate subjectivity and accommodate the case-specific nature of valuation for 
compensation for oil spill has continued over the years (Jackson, 2003); during which time economists have come up with a number of alternative approaches intended to provide reliable estimates for certain items in environmental valuations. These include the 'stated preferences' techniques which use statements about intended future behavior to draw conclusions about total economic values such as the contingent valuation and conjoint analysis; and the 'revealed preferences' such as hedonic pricing, which measures the value of an environmental asset by the estimated change in the value of a traded good as a result of the provision of the environmental asset, and, the travel cost method, whereby the value of an environmental asset is approximated by the willingness to pay of individuals to use the asset expressed in the costs incurred in travelling to the asset or as is often the case, a combination of these. Valuers must therefore be proficient in the choice and use of appropriate technique for various aspects of compensation assessment.

\section{Characteristics of the impact and the impacted area}

Oil spill is often accompanied with detrimental and far-reaching impacts on the atmosphere, soils and sediments, surface and groundwater, marine environment, biologically diversity and sustainability of terrestrial ecosystems. Crude oil contains more than 200 poisonous substances. Nigerian crude oil is in particular highly toxic (Egbe \& Thompson, 2010). The severity and impact of oil spills depend in part on the nature of the impacted area, the volume of the spills; the time it occurs; as well as the nature, effectiveness and the speed of the remedial measures. For instance, the effects of wind drift currents and waves in moving oil spills is less pronounced during dry season than wet season because the magnitude of the ocean current is less during dry season.

Oil contamination creates problems that disrupt the lives of people living in close proximity to oil wells, pumping stations, camps and pipelines. These include contamination of drinking water, top soil, and livestock. In some contaminated sites, serious illness of wildlife, livestock and human resulting from exposure have been documented. There is also loss of fishing rights due to oil spills in swamps, creeks and rivers resulting in significant death, lower production level and migration of fishes and other aquatic lives. Most times, the areas affected are largely rural where the only source of domestic water is from the rivers, creeks etc. which are often polluted. Drinking water has to be sourced at great expense and extra efforts otherwise the people are forced to drink polluted water at the risk of their health. For farmers, forest trees provide soil stabilization against erosion and other agents of denudation, increased soil fertility through leaf litter decay and wild life habitat. Therefore, loss of vegetation cover provided by the forest will lead to exposure of the area to soil erosion, decline in soil productivity and loss of farmland; causes flooding and siltation of water bodies which constitute serious environmental problems apart from the colossal loss in timber and wood and other economic trees. Also, loss of vegetation means loss of wild life habitats, diminished supply of bush-meat and hence reduce protein intake in the community, erosion of gene resources and extinction of plant and animal species that plays important roles in the life, culture and religion of the people.

Contamination often affects the utility of developed properties such that it takes longer to let, sell or the transaction may only be achieved at a lower rent or price. In addition, the value of a previously contaminated property may fail to return to previous levels despite remediation, owing to the stigma effect. The stigma effect arises because potential purchasers or tenants do not believe that the property is completely free from contamination even after the clean-up. Such market bias invariably results in reduction of property value. Apart from financial losses due to higher vacancy, operation and transaction costs, as well as remediation and monitoring costs, the adjoining land may become contaminated when contaminants are carried onto it by 
surface or groundwater, or simply by leaching or permeation. Where adjoining land is contaminated, the landowner of subject property is liable in tort to pay compensation.

On health grounds, oil pollution has been linked to headache, respiratory problems, frequent colds and sore throats, chronic coughs, skin rashes, eye irritation, dizziness and memory lapses. Long term effect may include increased risk of cancer, while children, elderly people and people with chronic ailments like asthma, allergies, heart and lung diseases seem especially vulnerable.

As compensation is intended to re-establish the status quo, the basis of valuation for injurious affection must take into consideration the damage to the use, non-use and option values of the ecosystem including diverse effects on humans, fishes and livestock. Use value reflects the direct use of environmental resources which comprise consumptive values; economic crops and trees; and hunting as well as scenic beauty conferred by natural vista. The non-use value includes values the community hold for the environmental resources such as preservation, bequest, birds watching and option value which reflect the value the community place on future ability to use the environment. It also covers biological resources other than timber such as fruits, nuts, oil seeds, resin, gum, medical plants and raw materials such as bamboo. These categories of claims relate to actual economic loss including injurious affection and disturbance beside other damages or losses suffered by the community as a direct consequence of oil pollution.

\section{Relevant statutes and civil laws}

Being a statutory valuation enabled by specific law(s), the computation and reporting of compensation for oil spillage must be guided foremost and essentially by the provisions of the enabling law, and any other relevant statutes and civil laws which, more often than not, prescribe the appropriate basis of valuation, method of valuation, and the 'heads of claims', among others.

Contaminated properties are subject to the regulation at both common and statutory laws. The substantive principles of law derived from statues law as well as case-law on compensation matters should therefore guide valuers in their valuations. For instance, under common law, the polluter or landowner may be sued by persons affected by contaminants for damages under strict liability, the tort of nuisance or trespass. A universal principle of compensation as established by the Court of Appeal in Britain in Bisney v. Swanston (1957) is that:

"The over-riding principle of compensation is to restore the plaintiff to the same position as before the tort was committed"

According to the Federal Environmental Protection Agency of Nigeria, the major national laws and international agreements on pollution and related matters that affect valuers' consideration and forms the basis of valuations for environmental pollution include the Nigerian Constitution (1999), Oil Pipelines Act 1990 Cap 07, LFN 2004, the Petroleum Act 1969 now Cap P10, LFN 2004, Mining Act No 24, 1999, the Oil in Navigational Water Act, Cap 06 LFN 2004, Endangered Species Decree Cap 108 LFN 1990, Federal Environmental Protection Agency Act Cap 131 LFN 1990, Harmful Waste Cap 165 LFN 1990 and the Land Use Act 1978 now Cap 202, LFN 2004, among others. Specifically, Section 20 of 1999 Constitution of the Federal Republic of Nigeria provides for the protection and improvement of the environment and safeguarding of water, air and land, forest and wildlife of Nigeria. In particular, it provides that compensation should be paid for damages to buildings, economic trees or crops by any person who surveys, digs or lays pipes for the supply and distribution of energy and fuel. The Oil Pipeline Act (1990) (now Cap 07, LFN, 2004) provides for 
compensation only when there is a leakage. Paragraph $3 \mathrm{~b}$ schedule 1 of the Petroleum Act provides that "the holder of and oil exploration license or oil mining lease shall in addition to any liability for compensation to which he may be subject under any of the provision of this Act, be liable to pay fair and adequate compensation for the disturbance of surface or other rights to any person who owns or in lawful occupation of the licensed or leased land". In addition, statutory requirements for post impact assessment are prescribed in the Environmental Guidelines and Standard for the Petroleum Industry in Nigeria (EGASPIN, 2002). Also, the Federal Environmental Protection Agency (FEPA), now part of the Federal Ministry of Environment, is legally vested with the responsibility of protecting and sustaining the Nigerian environment through formulation and implementation of regulatory frameworks.

Failure by valuers to adhere strictly to the provisions of relevant laws and regulations provide loopholes in his valuation which a defendant may exploit to discredit his evidence and claims, if the matter becomes a subject of litigation. Valuers must therefore be acquainted with relevant statutes and civil laws regarding compensation and how they may affect individual cases as they form the fundamental and ultimate basis for the court consideration and decisions.

\section{Professional practice standards and ethics}

Valuation being a profession, the Valuer is expected to carry out his job within the ambit of the practice standards and ethics prescribed by relevant professional body(s). As a matter of fact, the courts have always looked up to the published standards of professional bodies for judgment guidelines. While failure to comply with these standards does not automatically constitute a breach of the laws as they are not legislative enactments, the courts have always put these standards into consideration especially in liability cases such as negligence, breach of contract, and fraud (Shampton, Waller \& Waller, 1998). To help members understand and deal appropriately with valuation issues associated with environmental contamination, valuation professional bodies around the world publish guidelines or practice notes to assist members. For example, the Australian Institute of Valuers and Land Economists (now the Australian Property Institute) published the Contaminated Land Valuation Practice Standard in 1994. The document was subsequently incorporated into Guidance Note 15 "Reporting on Contaminated Land" of the API Professional Practice 2009 (API, 2009). Likewise, the Appraisal Institute of the USA make similar provisions in her Guide Note 8 of its Standards of Professional Appraisal Practice (The Appraisal Institute, 1994). In the United Kingdom, the Royal Institution of Chartered Surveyors has published a guidance note "Contamination and its Implications for Chartered Surveyors" (RICS, 1997). Similarly, the Appraisal Institute of Canada gives members similar guidance via Guide Note 5 of its Professional Standards.

In Nigeria, the property valuation profession is regulated by the Estate Surveyors and Valuers Registration Board of Nigeria (ESVARBON) established by Decree No 24 of 1975 now CAP E.13 of LFN 2007 in conjunction with the Nigerian Institution of Estate Surveyors and Valuers (NIESV). According to the latest Valuation Standards and Guidance Notes of the Nigerian Institution of Estate Surveyors and Valuers (2006), all valuation reports must comply with the Generally Accepted Valuation Principles (GAVP). Specifically, the 'Statement of Standards' section of the document provides that in carrying out compensation valuation for oil spillage, which is largely, a non-market valuation, the Valuer shall, among others:

i) Explain the analytical process undertaking in carrying out the valuation and present meaningful information used in the analysis;

ii) Ensure that the estimate of value is undertaken using appropriate methods and methodologies; 
iii) Provide sufficient information to permit those who read and rely on the report to fully understand its idea, reasoning, analysis, and conclusions;

iv) Describe the scope/extent of the work undertaken and the extent to which the property was inspected;

v) Fully and completely explain the valuation basis/approaches applied and the reasons for their applications and conclusions.

The 'Statement of Standards' section further provides that Estate Surveyors and Valuers should comply strictly with the ethics and standards stipulated by the International Valuation Standards Committee (IVSC), in their valuation construction and reporting. The IVSC's valuation Standards, provide, among others, that for a valuation to be credible, it is important that those judgments can be seen to have been made in an environment that promotes transparency and minimizes the influence of any subjective factors on the process (IVS, 2011). On competence, because valuation requires the exercise of skill and judgment, it is a fundamental expectation that valuations are prepared by an individual or firm having the appropriate technical skills, experience and knowledge of the subject of the valuation, the market in which it trades and the purpose of the valuation (IVS, 2011). For complex or large multi-asset valuations, it is acceptable for the Valuer to seek assistance from specialists in certain aspects of the overall assignment, provided this is disclosed in the scope of work (IVS, 2011). This is because a "typical appraiser (Valuer) is not technically qualified to detect contamination or the presence of hazardous substances. It has therefore become an accepted practice in the market place to hire a trained and experienced professional to conduct an environmental investigation as to the type of contamination affecting the property, the damage done, the level of cleanup required, the appropriate method of that cleanup, potential environmental risks and the costs.

Furthermore, because the Oil Companies responsible for most oil spills are largely foreign firms with activities spread all over the world; such valuations, to be credible, must conform, as much as possible, to international standards and best practices. In the emerging globalized world, valuations that would be relied upon internationally can be produced only by a valuation profession that conforms to international standards of professional education, competence and practice (Babawale \& Omirin, 2011).

\section{Scientific/laboratory investigations and tests}

Oil spills and the resultant damages to the ecosystem often requires extensive and exhaustive laboratory and scientific tests and investigations in order to ascertain the exact nature, extent and the cost implications of the impact, the required remedial measures and the residual effects, including stigma effect. Appropriate consultants in environmental assessment should therefore be engaged to carry out the required tests and scientific investigations. It is outside the purview of a real estate valuer to objectively and adequately assess the impact and cost implications of oil spillage on the eco-system, vegetation, microbes, aquatic lives, and human health without the input of relevant technical specialists. The relevant technical specialists in this instance include the Marine Biologists, Soil Scientists, Health and Safety experts, and Micro Biologists. These specialists undertake scientific investigations that help to ascertain the degree of pollution; loss of aquatic lives; loss of economic trees, crops; predict possible recovery period and remediation actions and the cost implications. For instance, the health implications of oil spills should be described, quantified and translated to monetary figure by a qualified medical practitioner via a medical report which should be attached to the valuer's report. It is from the results of such studies and/or investigations that the valuer derives authentic data for his valuation. 


\section{Case-laws}

Case law has remained the essential source for obtaining an understanding of the law relating to professional liability of Valuers in negligence by providing information on the court expectations in the light of the overall "reasonable care and skill" concept, the standard by which Valuers' work, like that of other professionals, are to be measured (Foster, Lavers and Waddell,1998). As such, Valuers are well advised, in their own interest, to keep abreast of court pronouncements in litigations relating to their calling. Case law or judicial precedence is that body of law derived from judicial decisions of courts or similar tribunals. In common law jurisdiction like Nigeria, where a similar dispute has been resolved in the past, the court is usually bound to follow the reasoning used in the prior decision. These laws made by judges, stands in contrast to and on equal footing with statutes which are adopted through the legislative process, and regulations which are promulgated by the executive arm of the government. A typical and relevant example is the insight provided by the court pronouncement in the celebrated case of 1989 Exxon Valdez which has continued to be of universal application in valuation for compensation for oil spillage (Roddewig, 1999) in The Appraisal Institute (2002). The principles established in this case include:

i) remediation costs, indemnification, and stigma are critical considerations;

ii) the impact of the oil spill on real estate is temporary;

iii) the impact is to be determined based on land use i.e. on a use-by-use-basis;

iv) the annual loss to the land can be expressed in terms of a lost economic rent;

v) the degree of economic impairment is a function of the highest and best use of the land prior to the oil spill; and

vi) the economic losses over time are to be discounted to a present value.

It was further established that there is no automatic direct correlation between physical persistence of oil and its effects on real estate; that the length and intensity of the cleaning up is the significant factor in determining the length of any potential real estate market impact. However, the actual length of the impact; the highest and best use especially for properties located in a remote or limited real estate market; the categorization of use, acreage, comparables and land values; the length of discount period and the appropriate "discount rate" are variables to be determined on individual's case merit.

Regarding admissibility of expert testimony, the US Daubert case where the conduct of expert witness is assessed with reference to what is known as the "Daubert Standard", is also of significance here. For a testimony or evidence to be relevant and reliable, the Daubert case, in addition to instructing the Court to act as gatekeeper, set forth the following minimum conditions, often referred to as "Daubert factors" for admitting a concept, an idea or a theory etc., as a basis of an expert witness testimony:

i) whether a theory and/or technique (e.g. valuation theory or methodology) has been tested;

ii) whether a theory and/or technique has been subject to peer review and/or has been published;

iii) the known or potential error rate of a technique, and the existence and maintenance of standards for use of that technique; and

iv) there are standards to control the operation of the technique; and

v) whether the theory or technique is well accepted within the "relevant scientific community.

In Kumbo Tire Co. v. Carmichael (1999), the US Supreme Court extended the Daubert's factors to cover all expert testimony, whether they are based on science, technology, skill and 
experience or not. It was also held that the Daubert's factors is a non-exhaustive list; thus, giving the trial judge "considerable leeway" in assessing the reliability of an expert opinion.

\section{The Local Property Market}

This is the totality of the legal, institutional, economic and regulatory factors within which property transaction is carried out and the valuer also carries out his professional duties in the locality. The local property market may be dynamic and highly complex which may be complicated by poor quality information and government legislations. The local market may be thin or stable, dull or active, with existing regulatory framework including public and private restrictions on ownership rights and dealings in property. Most activities that result in all spills take place in the rural communities where the property market is poorly developed and reliable transactional data on comparable properties usually difficult to come by. Most times, valuers are forced to rely on secondary information or are left with no other options than to make up for total lack of information by falling back on intuition or the rule of thumb. Often, the survey approaches (non-market methods) remain the only authentic alternative to obtain the required data and information.

\section{Quality control or assurance}

Finally, valuation firms are encouraged to put in place effective quality control system that would ensure that only diligently prepared and proven valuations pass through the system. This may include ensuring that all valuations pass through the desk of senior Valuers with several years of experience; that valuations are carried out by qualified and experienced Valuers that valuation reports are discussed on the floor of the valuation unit or department before they are sent out of the system; and that the firm maintains an up to date database. Where technical specialists are brought in to assist the Valuer in certain specialized area of a valuation assignment, the Valuer is expected to include in his valuation report the reputation, competence, and the degree of independence of such specialists, including how the contribution of the specialists has influenced his valuation opinion.

Quality control also provide answers to such pertinent queries such as: Does the report fulfil its purpose? Does the report answer and communicate the value question the Valuer is trying to establish convincingly, objectively, transparently, and precisely? Are all the illustration/figures/charts etc. clearly labelled, have appropriate/precise titles? etc.

Quality control also implies that each firm maintain up-to-date database; each firm should create her own valuation template (standard), educate the staff on the underlying concept and rationale, how to use it and then stick to it. Firms should have their checklist or procedural manual - a list of things that the Valuers must remember to do or find out in every category of valuation assignment.

\section{CONCLUSION AND RECOMMENDATIONS}

This study has demonstrated that valuation for compensation for environmental contamination of all sorts is multi-faceted, multi-dimensional and multi-disciplinary. This is contrary to the observed notion among the generality of valuers in the study area whereby several of the valuers/valuation firms presumptuously arrogate to themselves functions that is outside the purview of their professional training and expertise. Valuers professional standards at various levels recognize that a typical valuer is not technically qualified to detect contamination or the presence of hazardous substances talk less of putting an accurate cost on the required remedial actions and the overall impact on the ecosystem. It has therefore become an accepted practice in the market place to hire relevant trained and experienced professional to conduct necessary environmental investigations into the type of contamination and how 
properties are affected, the damage done, the level of cleanup required, the appropriate method of that cleanup, potential environmental risks and the costs. The International Valuation Standards Committee prescribed, among others, that valuations are to be prepared by an individual or firm having the appropriate technical skill, experience and knowledge of the subject of the valuation, the market in which it trades and the purpose of the valuation; and for complex or large multi-asset valuations, it is acceptable for the valuer to seek assistance from specialists in certain aspects of the overall assignment (IVSC, 2011). The relevant technical specialists in this case include the Marine Biologists, Soil Scientists, Health and Safety experts, and Micro Biologists or a consortium of environmentalists. This and similar shortcomings could be averted if valuers are provided and mandated to adhere strictly to appropriate framework in carrying out his valuation; a holistic model that reminds the valuers of all issues that are germane to a reliable assessment of compensation and how the issues are better addressed and reported.

A diligent application of the principles underling the model that this study proffers should guarantee compensation assessment process that is rational, logical, transparent, consistent and traceable - and ultimately a reliable and incontrovertible assessment. The improved compensation assessment practice would help to minimize the level of controversies, discontentment, delay, and high litigation costs often associated with compensation matters in the study area. To apply the framework proffered, Valuers in the study area would be required to hone their skill through capacity building particularly in the use of non-market valuation methods, which are purposely devised to deal with issues in environmental valuation that are not addressed or adequately addressed by any of the conventional valuation methods. The American Appraisal Institute particularly supports the use of the contingent valuation technique where properties suffer from contamination or other impairment or market failure which may occur for various reasons including lack of information and knowledge. This particular technique was used to damages in the celebrated Exxon Valdez oil spill of 1989 in America.

Valuation is information-driven. Valuers are not inventors of values. Valuers' duty is to predict market value based on intelligent interpretation of available market and/or industry data. Where no market evidences exist because the property is not traded in the open market or for some other reasons, or where the quality and quantity of available evidences are questionable, valuer's task is made problematic and his value estimates become suspect. Valuation techniques are as good; and the results they provide as reliable, as the quality of the data inputs. To this end, a National Valuation Evidence Database (NEVD), similar in nature to the Investment Property Databank (UK), should be established which will mutualize data on property transactions available in a particular market. It is expected that Valuers interested in gaining access to NEVD would contribute by supplying data and/or would subscribe for a fee to NEVD.

\section{References:}

Achebe, C.H., Nneke, U.C., and Anisiji, E.O. (2012). Analysis of Oil Pipeline Failures in the Oil and Gas Industries in the Niger Delta Area of Nigeria. Proceeding of the paper presented at the International Multi-conference of Engineers and Computer Scientists, Hong Kong (Vol II).

Amidu, A. (2006). A Study of Client Influence on Residential Property Valuation in Lagos Metropolis. A M.Sc. Thesis submitted to Department of estate management Obafemi Awolowo University, Ile-Ife. Nigeria.

Amidu, A. and Aluko, B.T. (2007). Client Influence on Valuation: Perceptual Analysis of the Driving Factors, International Journal of Strategic Property Management, 11, p.77-89.

API (2009). Australian Property Institute \& Property Institute of New Zealand (2009) : Australian and NEW Zealand Valuation and Property Standards. Deakin: API \& PINZ> Retrieved from http://property standards.propertyinstitute-wa.com/documents/ProfPracticeV6_000.pdf. 
Appraisal Institute (2002). Valuing Contaminated Properties: An Appraisal Institute Anthology. Appraisal Institute, Illinois, USA (Ed. Roddewig, R.J)

Babawale, G.K. (2008). “An Evaluation of factors influencing inaccuracy in residential property valuation in Lagos Metropolis". PhD thesis, Department of Estate Management, University of Lagos, Lagos.

Babawale, G.K. (2013). Emerging Issues in Compensation Valuation for oil Spillage in the Niger Delta area of Nigeria. Journal of Review on Global Economics, (2), 31 - 45.

Babawale, G.K. and Ominrin, M.M. (2011). Valuers' and Valuation Firms' Characteristics as Causes of Inaccuracy in Valuation. Mediterranean Journal of Social Sciences, 2 (3), 89-103.

Baum, A.E, Macgregor, B.D. (1992). The Initial Yield Revealed Explicit Valuations and the Future of Property Investment. Journal of Property valuation and Investment 10 (4), 709-726.

Bell, R. (2008). Real estate damages: Applied economics and detrimental conditions (2nd ed.) Chicago: Appraisal Institute.

Bowman, M. and Boyle, A.E. (2005). Environmental damages in International and Comparative Law: Problems of Definition \& Valuation. (http://books.google.com.ng/book?isbn=)

Byrne, P. (1996), Risk Uncertainty and Decision Making in Property Development, 2nd ed; E \& F.N. Spon, London.

Egbe, R.E. and Thompson, D. (2010). Environmental Challenges of Oil Spillage for Families in Oil Producing Communities of the Niger Delta Region. JHER , (13), 24-34.

Egbenta, I.R. and Uduudoh, F. P. (2017). Compensation for Land and Buildings Compulsorily Acquired in Nigeria: A Critique of the Valuation Technique. Property Management. Vol 36 (4), pp. 446 - 460.

Foster, H., Lavers, A. and Waddell, M (1998). A Database of Negligent Valuation Cases and Literature. Journal of Property Valuation \& Investment, 16(1), pp.87-98.

Hornby, A.S. (2018). Oxford Advanced Learner's Dictionary English (9th ed.), Oxford university Press.

Ifediora, G.S.A. (2009). Appraisal Framework: Lectures on Theory, Principles, Methods and Practice of Property Valuation, Enugu, Nigeria: Iwuba Ifediora and Associates.

IVSC, (2011). International Valuation Standards Committee: Principles, Standards, Applications and Performance Guidance. London: International Valuation Standards Committee.

Iyanda, A.S. (2014). Communal Land Acquisition and Valuation for Compensation in Nigeria. International Journal of Scientific and Research Publications, vol 4 (11)

Jackson, T.0. (2003). Methods and techniques for contaminated Property Valuation. The Appraisal Journal, 311320 (October).

Kakulu, I.I. (2008). Post Impact Environmental Assessment Surveys and Contaminated Land Valuation or Compensation in Nigeria. Unpublished Manuscript, Department of Estate Management, Rivers State University of Science and Technology, Port Harcourt.

Kakulu, I.I., Byrne, P., and Viitamen, K (2009). Phenomenological Research in Compulsory Land Acquisition and Compensation. Paper Delivered at Compulsory Purchase and Compensation and Valuation in real Estate Development. FIG Working week 2009 Surveyors key role for Accelerated Development, Eita, Israel.

Kakulu, I.I., Okorji, U., Mumeya, F., Izebe, S.E., \& Wokoma, T.N. (2014). New Compensation Systems and Mechanisms in the Oil and Gas Industry in Nigeria. DOI: 10.13140/Rg.2.1.2755.4004.

KPMG (2014). Overview of Nigerian Oil and Gas Industry. Klynveld, Peat, Marvick, and Goerdeler, Nigeria: KPMG.Nwilo, P.C. \& Badejo, O.T. (2005). Impacts and Management of Oil Spill Pollution along the Nigerian Coastal Area. Paper Presented at the International Oil Spill Conference, Miami.

Levy, D., Schuck, E. (1999). The Influence of Clients on Valuations, Journal of Property Investment and Finance, 22(3), p.259-268.

NIESV, (2006). Valuation Standards and Guidance Notes of the Nigerian Institution of Estate Surveyors and Valuers, Nigeria.

Quan, D.C. and Quigley, J.M. (1991). Price Formation and the Appraisal Function in Real Estate Markets. Journal of Real Estate Finance and Economics, (4), p. 127-46.

RICS, (1997). Guidance Notes on the Valuation of Assets, London: Royal Institution of Chartered Surveyors.

Roddewig, R.J. (1999), Recent Lessons from Litigation Trenches, The Appraisal Journal 
Shampton, F., Waller, T.H. and Waller, N. G. (1988). Appraiser Malpractice: Sources of Liability and Damages, The Appraisal Journal, July, p. 399-405.

The Appraisal Institute (2002). Valuing Contaminated Properties: An Appraisal Institute Anthology. Appraisal Institute, Illinois, USA.

Wilson, A.R. (1992). Environmentally impaired valuation: A team approach to a balance sheet presentation. Technical report: Measuring the effects of hazardous materials contamination in real estate values: Techniques applications, Appraisal Institute.

\section{Statutes:}

Endanger Species Decree Cap 108 LFN 1990.

Federal Environmental Protection Agency Act Cap 131 FLN 1990.

Harmful Waste Cap 165 LFN 1990

Land Use Act, 1978, now Cap 202, LFN 2004.

Mining Act No 24, 1999

National Environmental Standards and Regulations Enforcement Agency (NESREA) Act 2007

Oil in Navigation Waters Act 1968 Cap 06 LFN 2004

Oil Pipeline Act 1990 now cap 07 LFN 2004.

Petroleum Act 1969 now cap P10 LFN 2004.

The Constitution of the Federal Republic of Nigeria 1999 (S. 12, 20, 33 \& 34)

\section{Statutes \& Cases}

Kumbo Tire Company Ltd, et al, v. Patrick Carmicheal, 119 S. Ct. 1167 (1999).

Bisney v. Swanston (1957) 225 Estate Gazette 2299 